WellBeing International

WBI Studies Repository

2009

\title{
Relationship between pre-slaughter stress responsiveness and beef quality in three cattle breeds
}

\author{
V. Muchenje \\ University of Fort Hare \\ K. Dzama \\ Stellenbosch University \\ M. Chimonyo \\ University of Fort Hare \\ P. E. Strydom \\ Agricultural Research Council (South Africa) \\ J. G. Raats \\ University of Fort Hare
}

Follow this and additional works at: https://www.wellbeingintlstudiesrepository.org/slaapra

Part of the Agribusiness Commons, Animal Studies Commons, and the Operations and Supply Chain Management Commons

\section{Recommended Citation}

Muchenje, V., Dzama, K., Chimonyo, M., Strydom, P. E., \& Raats, J. G. (2009). Relationship between preslaughter stress responsiveness and beef quality in three cattle breeds. Meat science, 81(4), 653-657. https://doi.org/10.1016/j.meatsci.2008.11.004

This material is brought to you for free and open access by WellBeing International. It has been accepted for inclusion by an authorized administrator of the WBI Studies Repository. For more information, please contact wbisr-info@wellbeingintl.org.

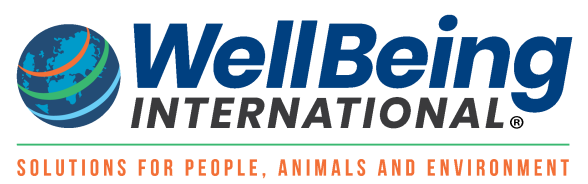




\title{
Relationship between pre-slaughter stress responsiveness and beef quality in three cattle breeds
}

\author{
V. Muchenje ${ }^{\mathrm{a}}$, K. Dzama ${ }^{\mathrm{b}}$, M. Chimonyo ${ }^{\mathrm{a}, *}$, P.E. Strydom ${ }^{\mathrm{c}}$, J.G. Raats $^{\mathrm{a}}$ \\ ${ }^{a}$ Department of Livestock and Pasture Science, University of Fort Hare, Private Bag X1314, Alice 5700, South Africa \\ ${ }^{\mathrm{b}}$ Department of Animal Sciences, Stellenbosch University, Private Bag X1, Matieland 7602, South Africa \\ ${ }^{\mathrm{c}}$ Meat Industry Centre, Department of Nutrition and Food Science, Agricultural Research Council, Private Bag X2, Irene 0062, South Africa
}

\section{A R T I C L E I N F O}

\section{Article history:}

Received 5 April 2008

Received in revised form 20 July 2008

Accepted 6 November 2008

\section{Keywords:}

Catecholamines

Correlations

Dopamine

$L^{*}$ value

Cooking loss

\begin{abstract}
A B S T R A C T
The relationship between stress responsiveness and beef quality of 40 Nguni, 30 Bonsmara and 30 Angus steers was determined. The $L^{*}$ values, pHu, cooking loss (CL) and Warner-Bratzler shear force (WBSF) were determined. Catecholamine levels were determined from urine samples collected at slaughter. Bonsmara steers had the highest $(P<0.05)$ levels of catecholamines with respective epinephrine, norepinephrine and dopamine concentrations of $10.8,9.7$ and $14.8 \mathrm{nmol} / \mathrm{mmol}$. Nguni steers had the lowest $(P<0.05)$ levels of catecholamines, with respective catecholamine concentrations of 5.1, 4.3 and $4.0 \mathrm{nmol} / \mathrm{mmol}$. In the Nguni steers, there were significant $(P<0.05)$ correlations between catecholamines and $L^{*}$ and between dopamine and tenderness in meat aged for two days (WBSF2). In the Bonsmara, dopamine was correlated $(P<0.05)$ pHu, WBSF2 and CL. No significant correlations were found in the Angus. Therefore the relationship between stress responsiveness and certain beef quality traits may not be similar in different breeds.
\end{abstract}

(c) 2008 Elsevier Ltd. All rights reserved.

\section{Introduction}

Pre-slaughter glycogen depletion in muscle may result in meat with a higher ultimate $\mathrm{pH}(\mathrm{pHu})$ (Kannan, Chawan, Kouakou, \& Gelaye, 2002), which is not always ideal for conversion of muscle to meat (Purchas, Yan, \& Hartly, 1999). Beef with pHu values higher than 6.0 is undesirable because of its dark colour (Bartos, Franc, Rehák, \& Stípková, 1993; Kreikemeier, Unruh, \& Eck, 1998; Mounier, Dubroeucq, Andanson, \& Veissier, 2006), high variation in tenderness (Silva, Patarata, \& Martins, 1999), increased water holding capacity (Apple, Kegley, Galloway, Wistuba, \& Rakes, 2005; Zhang, Farouk, Young, Wieliezko, \& Podmore, 2005) and poor palatability (Viljoen, De Kock, \& Webb, 2002; Wulf, Emnett, Leheska, \& Moeller, 2002). High pH also promotes growth of microorganisms which lead to the development of off-odours, and often slime formation (Gallo, Lizondo, \& Knowles, 2003; Gardner, McIntyre, Tudor, \& Pethick, 2001). It is important to determine the factors which affect the depletion of glycogen levels and the mechanism by which this occurs. Breed (King et al., 2006), feeding management, nutritional status (Andersen, Oksbjerg, Young, \& Therkildsen, 2005; Sañudo et al., 2004; Wheeler, Cundiff, Koch, \& Crouse, 1996), loading and transportation (Schaefer, Jones, \& Stanley, 1997; Mota-Rojas et al., 2006), temperament (King et al., 2006), pre-slaughter stress

\footnotetext{
* Corresponding author. Tel.: +27 40602 2101; fax: +27 406022488 .

E-mail address: mchimonyo@ufh.ac.za (M. Chimonyo).
}

and how the animals physiologically respond to stress (O'Neill, Webb, Frylinck, \& Strydom, 2006) are factors that affect glycogen depletion in animals and meat quality parameters such as $\mathrm{pHu}$, colour, cooking losses and tenderness.

Animals waiting for slaughter can be stressed by factors such as restraint, handling, novelty of the pre-slaughter environment, adverse weather conditions, hunger, thirst and fatigue (Apple et al., 2005; Fazio \& Ferlazzo, 2003; Grandin, 1997; Mormède et al., 2002). Catecholamines have been shown to cause depletion in muscle glycogen in the pre-slaughter period (O'Neill et al., 2006; Tarrant, 1989). Dopamine plays a part in the control of cortisol secretion and glycogen metabolism (Ahmadzadeh, Barnes, Gwazdauskas, \& Akers, 2006).

The concentrations of these hormones are the result of neuronal washout from tissues with sympathetic nerves and are therefore important indicators of sympathetic nervous system activity (Young, Rosa, \& Landsberg, 1984). Use of urinary stress hormones in assessing stress responsiveness is reliable because their measurement is non-invasive and their levels in urine are not affected by the massive release of catecholamines and dopamine associated with slaughter because there is a delay between elevation of their concentration in plasma and subsequent elevation in the urine (Hay, Meunier-Salau, Brulaud, Monnier, \& Mormède, 2000; Lay, Friend, Bowers, Grissom, \& Jenkins, 1992).

When an animal is stressed in the pre-slaughter environment, there is a rapid release of catecholamines which result in glycogen depletion (Lacourt \& Tarrant, 1985) causing high pHu and darker 
meat. Although Muchenje, Dzama, Chimonyo, Raats, and Strydom (2008) reported lower $L^{*}$ values in meat from Nguni steers than that of Bonsmara and Angus steers, they did not report pHu differences among the three breeds. The differences in $L^{*}$ values could not be full understood, although O'Neill et al. (2006) postulated that the differences could have been due to the Nguni releasing more catecholamines than the other breeds. While Foury et al. (2005) quantified relationships between stress responsiveness and hormones in pigs, most reports on stress responsiveness and meat quality are largely speculative and do not quantify the magnitude of the relationship between stress hormone levels and meat quality (Mota-Rojas et al., 2006; O'Neill et al., 2006; van Schalkwyk et al., 2000).

There is, therefore, need to evaluate the relationship between stress responsiveness and meat quality of Nguni, Bonsmara and Angus cattle raised under conditions that mimic rural conditions and management systems. The objective of the current study was to determine the relationship between stress responsiveness and meat quality characteristics of Nguni, Bonsmara and Angus when raised on natural pasture. The null hypothesis tested was that, under natural grazing, the relationship between stress responsiveness and the quality of meat from Nguni, Bonsmara and Angus breeds is similar.

\section{Materials and methods}

\subsection{Site description}

The study was conducted at University of Fort Hare Farm. The farm is $520 \mathrm{~m}$ above sea level and is located $32.8^{\circ} \mathrm{S}$ and $26.9^{\circ} \mathrm{E}$ Thirty castrated weaners each of Bonsmara and Angus breed, and 40 castrated weaners of the Nguni breed of similar age (205 \pm 2.1 days) were used. They were raised from the beginning of April 2006 until slaughter at the end of March 2007 at 18 months of age. The farm has an average annual rainfall of $480 \mathrm{~mm}$ and has a mean annual temperature of $18.7^{\circ} \mathrm{C}$. The vegetation type and management of steers has been described earlier (Muchenje et al., 2008).

\subsection{Animal handling and slaughter procedure}

On the day prior to slaughter, the 18 month steers were weighed off-pasture and were kept overnight at the abattoir holding pens without food. The three cattle breeds were randomly mixed in the pens. Water was available at all times. The steers from each pen were randomly moved from the pens to the knocking box. The average slaughter weight of the Nguni, Bonsmara and Angus steers were $224 \pm 6.7,260 \pm 7.2$ and $238 \pm 7.8 \mathrm{~kg}$, respectively. The average daily gains were $201 \pm 10.8,231 \pm 12.2$ and $189 \pm 14.1 \mathrm{~g} /$ day for Nguni, Bonsmara and Angus, respectively. Animal slaughter and dressing was done following standard commercial procedures at the East London Abattoir, South Africa. The captive bolt method was used to stun the animals. Carcasses were electrically stimulated $(300 \mathrm{~V}, 50 \mathrm{~Hz}$ and $5 \mathrm{~A})$ over $40-45 \mathrm{~s}$ at 12 pulse/s, to minimise the likelihood of cold shortening due to the rapid chilling regime used. Urine samples for hormonal determination were collected from the bladder of each animal approximately 12 min post-mortem into sample bottles, immediately after evisceration. The sample bottles contained $6 \mathrm{M}$ hydrochloric acid to stabilize the catecholamines. The samples were then frozen at $-20^{\circ} \mathrm{C}$, awaiting analysis.

Carcasses were split, weighed and then chilled at $0-3{ }^{\circ} \mathrm{C}$ before being processed the following day after slaughter. The $\mathrm{m}$. longissimus thoracis et lumborum (LTL) of the left and the right sides were sampled, a day after slaughter, from the 10th rib to third lumbar vertbrae in the following order and amounts for meat quality analyses:

(a) a $100 \mathrm{~mm}$ thick section of the anterior side of the left LTL for 2 day aged Warner-Bratzler shear force (WBSF2) tests and cooking loss (CL2) determination,

(b) a $100 \mathrm{~mm}$ thick section of the anterior side of the right LTL for 21 days aged Warner-Bratzler shear force (WBSF21) tests and cooking loss (CL21) determination,

(c) a $20 \mathrm{~mm}$ steak of the near posterior side of the left LTL for CIE Lab colour measurement.

This amounted to approximately $2.5 \mathrm{~kg}$ meat sample per animal

\subsection{Determination of stress hormone concentration}

The urine samples were first hydrolysed before the determination of catecholamines (Odink, Sandman, \& Schreurs, 1986). Catecholamines were extracted from the urine by cation-exchange solid phase extraction, and were determined by the High Performance Liquid Chromatography (HPLC)-method, as described by Gouarne, Foury, and Duclos (2004). Briefly, urine samples were loaded on cationic columns and the catecholamines were eluted with boric acid. The eluates were then assayed using HPLC with electrochemical detection with an oxidizing potential of $+65 \mathrm{~V}$. The catecholamines were then quantified against a calibration curve. Concentrations of catecholamines are volume-related (Hay et al., 2000) and for this reason catecholamine levels were expressed as ratios to creatinine concentrations.

\subsection{Beef quality measurements}

\subsubsection{Ultimate $p H, L^{*}$ value and Warner-Bratzler shear force determination}

Determination of $\mathrm{pHu}, L^{*}$ values and Warner-Bratzler shear force (WBSF) was as described by Muchenje et al. (2008). The procedures are briefly described as follows: A pH meter was used to measure the $\mathrm{pHu}$ of the LTL $24 \mathrm{~h}$ post-mortem. The $L^{*}$ values were measured with a minoltameter (Model CR200, Minolta, Japan) on fresh unaged samples ( 2 days post-mortem) according to the Commission International De I' Eclairage (CIE, 1976) procedure.

The sampled LTL to be used for shear force resistance were vacuum packed and either frozen directly (for those aged for 2 days) or aged at $2{ }^{\circ} \mathrm{C}$ for a further 19 days after processing ( 21 days in total) and frozen. Thirty millimeter steaks were prepared according to an oven-broiling method using direct radiant heat (American Meat Science Association, 1978). Following cooking, the steaks were cooled down at room temperature for $5 \mathrm{~h}$ before shear force determination. Eight sub-samples measuring $2.5 \mathrm{~mm}$ core diameter were cored parallel to the grain of the meat, and sheared perpendicular to the fibre direction using a Warner-Bratzler (WB) shear device mounted on an Universal Instron apparatus (cross head speed $=400 \mathrm{~mm} / \mathrm{min}$, one shear in the centre of each core). The mean maximum load recorded for the eight cores represented the average of the peak force in Newtons $(\mathrm{N})$ of each sample.

\subsubsection{Determination of cooking loss}

The sampled LTL to be used for cooking loss (CL) determination were vacuum packed and either frozen directly (for those aged for 2 days) or aged at $2{ }^{\circ} \mathrm{C}$ for a further 19 days after processing (21 days in total) and frozen. Two days before preparation, three steaks measuring $30 \mathrm{~mm}$ thick were cut with a band saw, vacuum packed and thawed over $24 \mathrm{~h}$ at $0-4{ }^{\circ} \mathrm{C}$. The steaks were prepared according to an oven-broiling method using direct radiant heat (American Meat Science Association, 1978). An electric oven was set on 
"broil" 10 min prior to preparation, at $260^{\circ} \mathrm{C}$. Steaks were placed on an oven pan on a rack to allow meat juices to drain during cooking and placed in the pre-heated oven $90 \mathrm{~mm}$ below the heat source. The steaks were cooked to an internal temperature of $35^{\circ} \mathrm{C}$ recorded by direct probe, then turned and finished to $70^{\circ} \mathrm{C}$. Raw and cooked weights were recorded. Following cooking, the steaks were cooled down at room temperature for $5 \mathrm{~h}$ before shear force determination. Percentage CL was calculated as:

[(weight of raw steak after thawing-weight of cooked steak)/ weight of raw steak after thawing] $\times 100$.

\subsection{Statistical analysis}

A total of 23 steers were excluded from the analyses for various reasons. Two Nguni and two Angus steers were stolen from the natural pastures. Since this was part of a study on organic meat production any steers that were treated for any disease were removed from the trial. Fourteen Angus and one Bonsmara steers that showed clinical signs of tick-borne diseases were treated and removed from the trial. Although there were records indicating ages of steers from the farms where they were bought, four Nguni steer carcasses were removed from analyses after they were detected by dentition to be older than the target age (18 months) at classification at the abattoir.

The effects of breed on catecholamines, $\mathrm{pH}, L^{*}$ values, WBSF and CL for meat samples that were aged for 2 or 21 days were analysed using Generalised Linear Models procedures of SAS (2000). Significant differences between least-square group means were compared using the PDIFF test of SAS (2000). Pearson's correlation coefficients between stress responsiveness hormonal concentration and $\mathrm{pHu}, L^{*}, \mathrm{WBSF}$ values and $C L$ values in all steers and within breeds were also determined (SAS, 2000).

\section{Results and discussion}

\subsection{Urinary catecholamine concentration}

Epinephrine, norepinephrine and dopamine levels of the three breeds are shown in Table 1 . There were breed effects $(P<0.05)$ on all the stress responsive hormones, with the Bonsmara having the highest $(P<0.05)$ and the Nguni having the lowest $(P<0.05)$ response to pre-slaughter challenges. This is in contrast to O'Neill et al. (2006) who found that the Nguni crosses had higher catecholamine levels at slaughter than those in Brahman crosses and the Simmental crosses. Our findings suggest that the Bonsmara steers were the ones that suffered the most pre-slaughter stress. In a study comparing several Bos taurus and Bos indicus breeds, Koch (2004) reported the Bonsmara to have the lowest levels of stress hormones. The differences in these results may be ascribed to the fact that animals' reactions to stress are governed by a complex interaction of genetic factors and previous experiences (Grandin, 1997; Mormède et al., 2002; Mounier et al., 2006). Previous expe-

Table 1

Least square means and standard errors of means (in parenthesis) of urinary catecholamine outputs from Nguni, Bonsmara and Aberdeen Angus steers.

\begin{tabular}{llll}
\hline \multirow{2}{*}{ Catecholamine } & Breed & & \\
\cline { 2 - 4 } & Nguni & Bonsmara & Angus \\
\hline$n$ & 34 & 29 & 14 \\
Norepinephrine $(\mathrm{nmol} / \mathrm{mmol})$ & $4.3(1.03)^{\mathrm{a}}$ & $9.7(1.36)^{\mathrm{b}}$ & $6.5(1.98)^{\mathrm{c}}$ \\
Epinephrine $(\mathrm{nmol} / \mathrm{mmol})$ & $5.1(1.30)^{\mathrm{a}}$ & $10.8(1.68)^{\mathrm{b}}$ & $6.7(3.21)^{\mathrm{a}}$ \\
Dopamine $(\mathrm{nmol} / \mathrm{mmol})$ & $4.0(0.27)^{\mathrm{a}}$ & $14.8(2.77)^{\mathrm{b}}$ & $7.2(2.2)^{\mathrm{c}}$
\end{tabular}

${ }_{\mathrm{abc}}$ Means in the same row with different superscripts are significantly different at $P<0.05$. riences may have affected results in this study since the animals used were bought from different farmers at weaning.

The findings in this study suggest that different types of animals have differing physiological and behavioural reactions to the same procedure (Lanier et al., 1995). Studies to determine the amount of stress on farm animals during routine handling and transport often have highly variable results and are difficult to interpret (Grandin, 1997). Genetic factors, including temperament, also influence the degree to which animals respond to stress (Fazio \& Ferlazzo, 2003; Grandin, 1997; Mormède et al., 2002). The relationship between stress responsiveness and glycogen depletion, and its resultant effect on meat quality parameters such as $\mathrm{pHu}$, colour, tenderness and cooking losses is, therefore, likely to be highly variable.

\subsection{Selected meat quality characteristics}

Table 2 shows the pHu, $L^{*}$, WBSF values and CL values of Nguni, Bonsmara and Angus steers. As reported earlier (Muchenje et al., 2008), meat lightness $\left(L^{*}\right)$ was the only meat quality trait that was significantly $(P<0.05)$ affected by breed. The $L^{*}$ value for Nguni meat was the lowest $(P<0.05)$ while that of the Angus was the highest $(P<0.05)$. There were no $(P>0.05)$ breed effects on $C L$ in the current study. However, the CL values were lower than those of Du Plessis and Hoffman (2007) that were slightly above 30\% in steers that were finished on natural and Razminowicz, Kreuzer, and Scheeder (2006) in pasture fed steers which averaged $30 \%$. During heating most drastic changes occur in meat, such as shrinkage and hardening of tissue and release of cooking juice. These changes are caused by structural changes of myofibrillar proteins and of membrane structures (Razminowicz et al., 2006).

\subsection{Relationship between stress responsiveness and selected meat quality characteristics}

Tables 3-5 show the correlation coefficients between stress responsiveness hormonal concentration and $\mathrm{pHu}, L^{*}, \mathrm{WBSF}$ and $\mathrm{CL}$. The Nguni was the only breed where significant $(P<0.05)$ relationships between epinephrine and norepinephrine and $L^{*}$ values and between dopamine and WBSF2 were observed (Tables 3-5). In the Bonsmara steers, there were positive correlations $(P<0.05)$ between dopamine and $\mathrm{pHu}$ (Table 5 ). There were also negative relationships $(P<0.05)$ between dopamine, and WBSF2, and CL. In Angus steers, there were no $(P>0.05)$ relationships between stress responsiveness hormonal concentrations and all the studied meat quality traits. However, it must be stressed that the correlation coefficients in Angus steers should be treated with caution because of the smaller sample size used as compared with the sample sizes for the other two breeds. As expected, there was a negative

\section{Table 2}

Least square means and standard errors of means (in parenthesis) of selected beef quality characteristics of Nguni, Bonsmara and Aberdeen Angus steers.

\begin{tabular}{llll}
\hline & \multicolumn{3}{l}{ Breed } \\
\cline { 2 - 4 } Meat quality characteristic & Nguni & Bonsmara & Angus \\
\hline$n$ & 34 & 29 & 14 \\
Lightness $\left(L^{*}\right)$ & $37.0(0.54)^{\mathrm{a}}$ & $40.1(0.53)^{\mathrm{b}}$ & $40.4(0.65)^{\mathrm{b}}$ \\
WBSF2 $(\mathrm{N})$ & $42.1(3.33)$ & $46.1(3.14)$ & $42.1(3.04)$ \\
WBSF21 $(\mathrm{N})$ & $31.4(1.76)$ & $34.3(1.67)$ & $36.3(1.37)$ \\
pHu & $5.8(0.06)$ & $5.7(0.04)$ & $5.6(0.02)$ \\
CL2 $(\%)$ & $24.8(1.07)$ & $24.3(0.42)$ & $25.3(0.49)$ \\
CL21 $(\%)$ & $23.6(0.48)$ & $24.1(0.45)$ & $24.9(0.62)$ \\
\hline
\end{tabular}

${ }^{\mathrm{ab}}$ Means in the same row with different superscripts are significantly different at $P<0.05$; WBSF2 - Warner-Bratzler shear force value for meat aged for 2 days; WBSF21 - Warner-Bratzler shear force value for meat aged for 21 days; CL2 (\%) Cooking loss after aging for 2 days; CL21 (\%) - Cooking loss after aging for 21 days. 
Table 3

Correlations between epinephrine from urine and meat lightness $\left(L^{*}\right), \mathrm{pHu}$, tenderness and cooking loss of beef from all, Nguni, Bonsmara and Angus steers.

\begin{tabular}{lrrrr}
\hline Meat quality characteristic & \multicolumn{2}{l}{ Epinephrine } & \\
\cline { 2 - 5 } & \multicolumn{1}{l}{ All } & Nguni & Bonsmara & Angus \\
\hline Lightness $\left(L^{*}\right)$ & -0.13 & $-0.65^{* *}$ & -0.07 & -0.77 \\
pHu & -0.10 & 0.02 & 0.00 & 0.32 \\
WBSF2 (N) & 0.11 & 0.21 & -0.15 & 0.84 \\
WBSF21 $(\mathrm{N})^{\mathrm{b}}$ & 0.20 & 0.42 & -0.23 & 0.36 \\
Cooking loss 2 (\%) & -0.13 & -0.29 & 0.09 & 0.55 \\
Cooking loss 21 $^{\mathrm{c}}$ d & 0.04 & -0.09 & 0.22 & -0.22
\end{tabular}

Significantly correlated at ${ }^{* *} P<0.01$.

a WBSF2 - Warner-Bratzler shear force value for meat aged for 2 days.

b WBSF21 - Warner-Bratzler shear force value for meat aged for 21 days.

c CL2 (\%) - Cooking loss after aging for 2 days.

${ }^{d}$ CL21 (\%) - Cooking loss after aging for 21 days.

Table 4

Correlations between norepinephrine from urine and meat lightness $\left(L^{*}\right), \mathrm{pHu}$ tenderness and cooking loss of beef from all, Nguni, Bonsmara and Angus steers.

\begin{tabular}{|c|c|c|c|c|}
\hline \multirow[t]{2}{*}{ Meat quality characteristic } & \multicolumn{4}{|c|}{ Norepinephrine } \\
\hline & All & Nguni & Bonsmara & Angus \\
\hline Lightness $\left(L^{*}\right)$ & 0.00 & $-0.52^{*}$ & 0.04 & -0.82 \\
\hline $\mathrm{pHu}$ & 0.09 & 0.13 & -0.01 & 0.41 \\
\hline WBSF2 $(\mathrm{N})^{\mathrm{a}}$ & 0.14 & 0.13 & 0.00 & 0.79 \\
\hline WBSF21 $(\mathrm{N})^{\mathrm{b}}$ & 0.12 & 0.13 & -0.16 & 0.38 \\
\hline Cooking loss $2(\%)^{\mathrm{c}}$ & -0.10 & -0.30 & -0.10 & 0.47 \\
\hline Cooking loss $21(\%)^{\mathrm{d}}$ & 0.00 & -0.29 & 0.19 & -0.26 \\
\hline
\end{tabular}

Significantly correlated at ${ }^{*} P<0.05$.

a WBSF2 - Warner-Bratzler shear force value for meat aged for 2 days.

b WBSF21 - Warner-Bratzler shear force value for meat aged for 21 days.

c CL2 (\%) - Cooking loss after aging for 2 days.

d CL21 (\%) - Cooking loss after aging for 21 days.

\section{Table 5}

Correlations between dopamine from urine and meat lightness $\left(L^{*}\right), \mathrm{pHu}$, tenderness and cooking loss of beef from all, Nguni, Bonsmara and Angus steers.

\begin{tabular}{lcccr}
\hline Meat quality characteristic & \multicolumn{2}{l}{ Dopamine } & & \\
\cline { 2 - 5 } & All & Nguni & Bonsmara & Angus \\
\hline Lightness $\left(L^{*}\right)$ & 0.09 & -0.14 & -0.39 & 0.54 \\
pHu & -0.04 & -0.22 & $0.54^{*}$ & -0.20 \\
WBSF2 $(\mathrm{N})^{\mathrm{a}}$ & -0.10 & $0.53^{*}$ & $-0.52^{*}$ & -0.80 \\
WBSF21 $(\mathrm{N})^{\mathrm{b}}$ & 0.12 & 0.29 & -0.13 & -0.73 \\
Cooking loss 2 $(\%)^{\mathrm{c}}$ & -0.12 & 0.00 & $-0.62^{*}$ & -0.57 \\
Cooking loss 21 $(\%)^{\mathrm{d}}$ & -0.18 & -0.02 & $-0.61^{*}$ & 0.61 \\
\hline
\end{tabular}

Significantly correlated at ${ }^{*} P<0.05$.

a WBSF2 - Warner-Bratzler shear force value for meat aged for 2 days.

b WBSF21 - Warner-Bratzler shear force value for meat aged for 21 days.

c CL2 (\%) - Cooking loss after aging for 2 days.

${ }^{d}$ CL21 (\%) - Cooking loss after aging for 21 days.

correlation $(P<0.05)$ between pHu and $L^{*}$ in Bonsmara $(-0.58$, $P<0.001)$ and Angus $(-0.6, P<0.05)$. However, there was no $(P>0.05)$ relationship between pHu and $L^{*}$ in the Nguni steers. Furthermore, the Nguni meat was the darkest $(P<0.05)$ among the three breeds (Table 2 ).

The results found in this study confirm the varied nature of stress responsiveness of animals (Grandin, 1997; Koch, 2004) and its effects on meat quality, especially, $\mathrm{pHu}, L^{*}$ and tenderness. It is not clear why the Nguni steers which had the darkest meat among the three breeds had the lowest levels of catecholamines. Furthermore, the Nguni was the only breed whose meat had significant relationships between epinephrine and norepinephrine, and $L^{*}$ dopamine and WBSF for meat aged for two days while it did not have a relationship between pHu and $L^{*}$. It is expected that sympathetic activation before slaughter increases muscle glycogenolysis and, therefore, reduces lactic acid production post-mortem and meat acidification (Fernandez \& Tornberg, 1991). Significant glycogen depletion will result in high pHu, darker and tougher meat (O'Neill et al., 2006). Foury et al. (2005) found catecholamine levels to be positively correlated with pork pHu measured $24 \mathrm{~h}$ after slaughter. However, it is worth noting that this relationship varies considerably between muscles, depending on their metabolic properties and their sensitivity to catecholamines (Larzul, Le Roy, Monin, \& Sellier, 1998).

Differences in meat colour have also been associated with variations in intramuscular fat, moisture content and age dependent changes in muscle myoglobin content (Purchas et al., 1999). Although correlations between meat colour and intramuscular fat and moisture content were not determined in the current study, there were significant correlations in an earlier study (Muchenje et al., 2008). Our results imply that the darker meat colour in Nguni could be attributed to some other biochemical and physiological factors as opposed to glycogen depletion and rise in pHu. O'Neill et al. (2006) reported a marginally slower decrease in carcass $\mathrm{pH}$ in Nguni crosses as compared to Brahman crosses and Simmental crosses when they were raised in a feedlot. It is also important to determine whether the variations found in urinary levels of hormones result from differences in basal secretion or in the intensity of the response to pre-slaughter stress or in both (Foury et al., 2005). There is a need to conduct research on nutritional status, urinary hormonal levels, the biochemical changes that take place during glycogen depletion, glycolytic potential, changes in pHu and their effect on colour changes in Nguni cattle raised on natural pasture to understand the complex nature of the relationships. The findings of this study suggest that the relationship between stress responsiveness hormones and $\mathrm{pHu}, L^{*}$, tenderness and cooking tend to be complex. This agrees with Grandin (1997) who argued that genetic factors, including temperament, influence the degree to which animals respond to stress. Zavy, Juniewicz, Phillips, and Von Tungeln (1992) found that the Brahman cross cattle had higher cortisol levels when restrained in a squeeze chute than English crosses.

Results in the current study suggest that the relationship between stress responsiveness and glycogen depletion and meat quality is complex. Unfortunately, the relationship between stress responsiveness and glycogen depletion was not determined in this study. In pigs, a high correlation between basal urinary cortisol level (urine collected in the farm) and post-stress level measured after transportation was reported (Mormède et al., 2002), suggesting that the levels measured at slaughter may indeed reflect basal HPA axis activity. Factors such as breed (King et al., 2006; Zavy et al., 1992), feeding management, nutritional status (Andersen et al., 2005; Wheeler et al., 1996), transporting (Schaefer et al., 1997) and temperament (King et al., 2006) need to be considered determining the effects of stress responsiveness on glycogen and meat. The animals' previous experiences (Grandin, 1997; Mounier et al., 2006), basal levels measured when urine is collected in the farm and levels measured after slaughter (Foury et al., 2005) also need to be considered.

\section{Conclusion}

While catecholamines were related to some meat quality characteristics in beef from Nguni and Bonsmara steers no relationships were reported in beef from Angus steers. Relationships among catecholamines and meat quality traits also differed with the duration of aging. While levels of urinary catecholamines can be useful indicators of pre-slaughter stress responsiveness their relationship with $\mathrm{pHu}, L^{*}$, tenderness and cooking tend to be complex. There is need, 
however, to determine the biochemical changes that take place in relation to stress responsiveness and the depletion of glycogen and its effects on beef quality of cattle raised on natural pasture.

\section{Acknowledgements}

This research was funded by the Kellogg - Foundation Project 388 at the University of Fort Hare. The steers were slaughtered at the East London Abattoir. The meat samples were analysed at the Agricultural Research Council (ARC) Meat Industry Centre at Irene, Pretoria. Catecholamines in urine samples were analysed at Ampath Laboratories in Pretoria.

\section{References}

Ahmadzadeh, A., Barnes, M. A., Gwazdauskas, F. C., \& Akers, R. M. (2006). Dopamine antagonist alters serum cortisol and prolactin secretion in lactating Holstein cows. Journal of Dairy Science, 89, 2051-2055.

AMSA (1978). Guidelines for cooking and sensory evaluation of meat. American meat science association. Chicago, IL: National Livestock and Meat Board.

Andersen, H. A., Oksbjerg, N., Young, J. F., \& Therkildsen, M. (2005). Feeding and meat quality - a future approach. Meat Science, 70, 543-554.

Apple, J. K., Kegley, E. B., Galloway, D. L., Wistuba, T. J., \& Rakes, L. K. (2005). Duration of restraint and isolation stress as a model to study the dark-cutting condition in cattle. Journal of Animal Science, 83, 1202-1214.

Bartos, L., Franc, C., Rehák, D., \& Stípková, L. (1993). A practical method to prevent dark-cutting (DFD) in beef. Meat Science, 34, 275-282.

Commission International Del' Eclairage (1976). Colorimetry (2nd ed.). Vienna, Switzerland: CIE.

Du Plessis, I. \& Hoffman, L. C. (2007). Effect of slaughter age and breed on the carcass traits and meat quality of beef steers finished on natural pastures in the arid subtropics of South Africa. South African Journal of Animal Science, 37, 143-153.

Fazio, E., \& Ferlazzo, A. (2003). Evaluation of stress during transport. Veterinary Research Communications, 27(Suppl.), 519-524.

Fernandez, X., \& Tornberg, E. (1991). A review of the causes of variation in muscle glycogen content and ultimate $\mathrm{pH}$ in pigs. Journal Muscle Foods, 2, 209-235.

Foury, A., Devillers, N., Sanchez, M. P., Griffon, H., Le Roy, P., \& Mormède, P. (2005). Stress hormones, carcass composition and meat quality in large white $\mathrm{x}$ duroc pigs. Meat Science, 69, 703-707.

Gallo, C., Lizondo, G., \& Knowles, T. G. (2003). Effects of journey and lairage time on steers transported to slaughter in Chile. Veterinary Record, 152(12), 361-364.

Gardner, G. E., McIntyre, B. L., Tudor, G. D., \& Pethick, D. W. (2001). The impact of nutrition on bovine muscle glycogen metabolism following exercise. Australian Journal of Agricultural Research, 52, 461-470.

Gouarne, C., Foury, A., \& Duclos, M. (2004). Critical study of common conditions of storage glucocorticoids and catecholamines in $24 \mathrm{~h}$ urine collected during resting and exercising conditions. Clinical Chimica Acta, 348, 207-214.

Grandin, T. (1997). Assessment of stress during handling and transport. Journal of Animal Science, 75, 249-257.

Hay, M., Meunier-Salau, M. C., Brulaud, F., Monnier, M., \& Mormède, P. (2000). Assessment of hypothalamic-pituitary-adrenal axis and sympathetic nervous system activity in pregnant sows through the measurement of glucocorticoids and catecholamines in urine. Journal of Animal Science, 78, 420-428.

Kannan, G., Chawan, C. B., Kouakou, B., \& Gelaye, B. (2002). Influence of packaging method and storage time on shear value and mechanical strength of intramuscular connective tissue of chevon. Journal of Animal Science, 80, 2383-2389.

Koch, J. W. (2004). The influence of tropical adaptation and breed type on adrenal and testicular function in beef bulls. PhD Thesis, Texas A\&M University, USA, pp. 248.

Kreikemeier, K. K., Unruh, J. A., \& Eck, T. P. (1998). Factors affecting the occurrence of dark-cutting beef and selected carcass traits in finished beef cattle. Journal of Animal Science, 76, 388-395.

King, D. A., Morgan, W. W., Miller, R. K., Sanders, J. O., Lunt, D. K., Taylor, J. F., et al. (2006). Carcass merit between and among family groups of Bos indicus crossbred steers and heifers. Meat Science, 72, 496-502.
Lacourt, A., \& Tarrant, P. V. (1985). Glycogen depletion patterns in myofibres of cattle during stress. Meat Science, 15, 85-100.

Lanier, E. K., Friend, T. H., Bushong, D. M., Knabe, D. A., Champney, T. H., \& Lay, D. G. Jr., (1995). Swim habituation as a model for eustress and distress in the pig. Journal of Animal Science, 73(Suppl. 1), 126. Abstract.

Larzul, C., Le Roy, P., Monin, G., \& Sellier, P. (1998). Variabilité génétique du potentiel glycolytique du muscle chez le porc. INRA Productions Animales, 11, 183-197.

Lay, D. C., Jr., Friend, T. H., Bowers, C. L., Grissom, K. K., \& Jenkins, O. C. (1992). A comparative physiological and behavioral study of freeze and hot-iron branding using dairy cows. Journal of Animal Science, 70, 1121-1130.

Mormède, P., Courvoisier, H., Ramos, A., Marissal-Arvy, N., Ousova, O., \& Désautés, C. (2002). Molecular genetic approaches to investigate individual variations in behavioural and neuroendocrine stress responses. Psychoneuroendocrinology, 27, 563-583.

Mota-Rojas, D. Becerril, M., Lemus, C. Sánchez, P., González, M. Olmos, S. A., et al. (2006). Effects of mid-summer transport duration on pre- and post-slaughter performance and pork quality in Mexico. Meat Science, 73, 404-412.

Mounier, L., Dubroeucq, H., Andanson, S., \& Veissier, I. (2006). Variations in meat pH of beef bulls in relation to conditions of transfer to slaughter and previous history of the animals. Journal of Animal Science, 84, 1567-1576.

Muchenje, V., Dzama, K., Chimonyo, M., Raats, J. G., \& Strydom, P. E. (2008). Meat quality of Nguni, Bonsmara and Aberdeen Angus steers raised on natural pasture in the Eastern Cape, South Africa. Meat Science, 79, 20-28.

Odink, J., Sandman, H., \& Schreurs, W. H. P. (1986). Determination of free and total catecholamines and salsolinol in urine by ion-pair reversed-phase liquid chromatography with electrochemical detection after a one-step sample clean-up. Journal of Chromatography, 377, 145-154.

O'Neill, H. A., Webb, E. C., Frylinck, L., Strydom, P. E. (2006). The stress responsiveness of three different beef breed types and the effect on ultimate $\mathrm{pH}$ and meat colour. In Proceedings 52nd international congress of meat science and technology (pp. 181-182). 13-18 August 2006, Dublin, Ireland.

Purchas, R. W., Yan, X., \& Hartly, D. G. (1999). The influence of a period of ageing on the relationship between ultimate $\mathrm{pH}$ and shear values of beef $M$. Longissimus thoracis. Meat Science, 51, 135-144.

Razminowicz, R. H., Kreuzer, M., \& Scheeder, M. R. L. (2006). Quality of retail beef from two grass-based production systems in comparison with conventional beef. Meat Science, 73, 351-361.

Sañudo, C., Macie, E. S., Olleta, J. L., Villarroel, M., Panea, B., \& Alberti, P. (2004). The effects of slaughter weight, breed type and ageing time on beef meat quality using two different texture devices. Meat Science, 66, 925-932.

SAS (2000). SAS user's guide: statistics (Version $6 \mathrm{Ed}$.). Cary, NC: SAS Inst. Inc.

Schaefer, A. L., Jones, S. D. M., \& Stanley, R. W. (1997). The use of electrolyte solutions for reducing transport stress. Journal of Animal Science, 75, 258-265.

Silva, J. A., Patarata, L., \& Martins, C. (1999). Influence of ultimate pH on bovine meat tenderness during ageing. Meat Science, 53, 453-459.

Tarrant, P. V. (1989). Animal behavior and environment in the dark-cutting condition in beef - a review. Irish Journal of Food Science and Technology, 13, $1-21$.

Van Schalkwyk, S. J., Cloete, S. W. P., Hoffman, L. C., Brand, Z., Pfister, A. P., \& Punt, K. (2000). The effect of pre-slaughter stress resulting from feed withdrawal on meat quality characteristics in ostriches. South African Journal of Animal Science, 30(Suppl.), 147-148.

Viljoen, H. F., De Kock, H. L. \& Webb, E. C. (2002). Consumer acceptability of dark, firm and dry (DFD) and normal pH beef steaks. Meat Science, 61, 181-185.

Wheeler, T. L., Cundiff, L. V., Koch, R. M., \& Crouse, R. D. (1996). Characterisation of biological types of cattle (cycle IV): Carcass traits and longissimus palatability. Journal of Animal Science, 74, 1023-1035.

Wulf, D. M., Emnett, R. S., Leheska, J. M., \& Moeller, S. J. (2002). Relationships among glycolytic potential, dark-cutting (dark, firm, and dry) beef, and cooked beef palatability. Journal of Animal Science, 80, 1895-1903.

Young, J. B., Rosa, R. M., \& Landsberg, L. (1984). Dissociation of sympathetic nervous system and adrenal medullary responses. American Journal of Physiology, 247, $35-40$

Zavy, M. T., Juniewicz, P. E., Phillips, W. A., \& Von Tungeln, D. L. (1992). Effects of initial restraint, weaning and transport stress on baseline and ACTH stimulated cortisol responses in beef calves of different genotypes. American Journal of Veterinary Research, 53, 551-559.

Zhang, S. X., Farouk, M. M., Young, O. A., Wieliezko, K. J., \& Podmore, C. (2005). Functional stability of frozen normal and high $\mathrm{pH}$ beef. Meat Science, 69, 346-765. 